\title{
Factor contributing to the success of cultural event management: The Phanom Rung Festival, Burirum province, Thailand
}

\author{
P. Thanee \\ Tourism Department, Faculty of Liberal Arts, \\ Ubon Ratchathani University, Thailand
}

\begin{abstract}
The aim to the study was to examine the factors that contribute to successful cultural festival management and how do those factors have an influence on sustainable tourism at The Phanom Rung Festival, Burirum province. The research focused on visitors and organizers opinion toward the management effectiveness of the Festival. In summary, managing a cultural festival successfully requires that organizers realize with following factors: the production and representation of the festival programs which interpreted how important of the festival and the venue as well as the cultural value to the people and community. Also, the management of facilities and infrastructures are needed. Moreover, the cooperation among organizers as well as raising awareness toward the festival and venue value is strongly needed. Finally, this festival was another one sample which acts as a tool to manage and preserve local heritage which was another way to develop sustainable tourism.
\end{abstract}

Keywords: factors, The Phanom Rung Festival, cultural event management.

\section{Introduction}

Festivals are a worldwide phenomenon that are represented in various forms such as dance, drama, comedy, film, music, the arts, crafts, ethnic and indigenous cultural heritage, religious traditions, historically significant occasions, sporting events, food and wine, seasonal rites, and agricultural products [1]. With a variety of purposes, festivals are performed differently by diverse groups but share common purposes to reveal experiences, revitalize 
traditions, build community pride, validate community groups, increase community participation, introduce new and challenging ideas and expand cultural perspectives [2]. In Thailand, there are lots of similar festivals, but different in form depending on the identity of each area, and cultural set-up in each community such as religion, tradition, animism, faith and belief, royal ceremony, way of life and pop culture. One of the festivals which are held for celebrating faith and belief as well as representing both the Thai and Khmer culture is The Phanom Rung Festival of Burirum province. This festival has been held annually for a long time at The Phanom Rung Sanctuary. The purpose of the festival is making worship to the holy object at the Phanom Rung Sanctuary, as well as, people believe that if they attended the festival once in their life, it would make them be happy, healthy, and wealthy. Therefore, there are lots of people attending the festival every year. The Phanom Rung Festival was originally founded in 1938 on the full moon period of the fifth month (in April) by the Buddhist abbot, Phra Opasdhammayan and the local residents. With the main purpose to praise and make worship to the sacredness of the Phanom Rung Sanctuary, the Festival was also held to increase the involvement of the community, share experiences between residents, and promote the Festival to the people in the surrounding area [3]. It was not until 1991 that the Festival became popular and three major organizations; namely, the office of Burirum province, the office of Phanom Rung Historical Park, and the Tourism Authority of Thailand (Northeast Region 1) stepped in and developed this Festival to become an annual cultural event in order to promote it widely as well as attract lots of visitors to attend [4]. The main theme of the festival was still making worship to the holy Phanom Rung Sanctuary. Moreover, the organizers expanded the duration of the festival into two days in the first weekend of April (for this year 2005 the Festival period is 2-3 April). Different activities and attractions during the Festival range from a traditional parade, artistic performances, light and sound performance, contests, and exhibitions to the sales of local products such as the OTOP Fair (One Tambon One Product). Not only embracing the modern activities, The Phanom Rung Festival is also comforted by various conveniences such as facilities ready to serve tourism demands, roads connecting the sanctuary to the city, a number of accommodation premises and restaurants, parking and souvenir spaces, as well as well-designed landscape surrounding the Phanom Rung Sanctuary. There is clear indication to support The Phanom Rung Festival as a product for cultural tourism in Thailand.

As mentioned above lead to justification to the research in two aspects. What are crucial factors contributing to the success in cultural event management, also how those factors have an influence on sustainable tourism at The Phanom Rung Festival, Burirum province.

\subsection{Research objectives}

To examine factors that contributed to the success in cultural event management and how do those factors have an influence on sustainable tourism at The Phanom Rung Festival, Burirum province. 
To explore visitors and organizers' opinions about the management of The Phanom Rung Festival in order to identify the factors that contributes to the success of cultural event management.

To study the cultural event management process and recommend effective guidelines for improving The Phanom Rung Festival.

\subsection{Literature reviews}

This study was concerned with event management; therefore in order to make a comprehensive understanding the researcher's purpose was to examine the event details in various perspectives; such as the event management system, the characteristics of event, and the evolution of the festival. The following definitions are related to the study.

The definition of the events; an event is the traditional phenomenon, which identifies the character and importance of the people, community, society, places, locality, and nation [2]. Similarly, [5] said that events are specific rituals, presentations, performances, or celebrations that are consciously planned and created to mark special occasions and/or to achieve particular social, cultural or corporate goals and objectives.

The Event Management System; the model consists of four interrelated fields: the event, internal environment, community context, and general environment. Each of these fields is interrelated as it affects the others through various inputs and outputs. [6] defined inputs as "all those things needed to operate the organization and produce the event" outputs become "management functions and event production activities."

The Characteristics of Event; these characteristics can be grouped together as having: uniqueness, perishability, labor intensiveness, fix time scales, intangibility, personal interaction, ambience, and ritual or ceremony [7].

\subsection{The evolution of the festival}

Historical background and significance of the festival; there is no evidence to inform the festival day before 1938, but it has been considered that it was held during the third month to the fifth month of the year. During 1938-1990, The Phanom Rung Festival has been celebrated on the full moon period of the fifth month (according to the Thai lunar calendar is April) by the abbot, Phra Opasdhammayan and local residents in the area. The major purpose of this festival is to pray and make worship to the sacredness of the Sanctuary as well as increase community participation, and share experiences between residents and people from surrounding areas, as well as admire the magnificence of the Phanom Rung Sanctuary [3]. The programs and activities comprise paying respect to the sacredness; pouring water ceremony on a Buddhist monk and relatives, listening to the Buddhist sermon, and playing traditional games and competitions, too. As The Phanom Rung Festival is based on the beliefs and faith 
of the people to the holy place and the sacredness of the sanctuary, people who come to the place should be careful of their behaviour, both physically and verbally. People must be well behaved during the festival's ceremony as well as be courteous and not argue [8].

Table 1: $\quad$ Comparing the evolution of The Phanom Rung Festival program.

\begin{tabular}{|c|l|l|}
\hline \multirow{4}{*}{ Day } & \multicolumn{2}{|c|}{ Programs and Activities } \\
\cline { 2 - 3 } & $\begin{array}{l}|c| \\
\text { - Paying respect to the sacredness } \\
\text { - Pouring water ceremony on a } \\
\text { Buddhist monk and relatives } \\
\text { - Listening to the Buddhist } \\
\text { sermon } \\
\text { - Playing traditional games and } \\
\text { competitions }\end{array}$ & $\begin{array}{l}\text { - The grand worshipping } \\
\text { procession }\end{array}$ \\
\hline Night & \multicolumn{1}{|c}{ - The ten-god vehicle parade } \\
\hline
\end{tabular}

The development of the festival's functions and forms; in ancient times, this festival was only for making the holy object at the Phanom Rung Sanctuary by the local people and the abbot. Since 1991 under the cooperation of the three major organizers: the office of Burirum province, the office of Phanom Rung Historical Park, and Tourism Authority of Thailand (Northeast Region 1) have developed the presentation form of the festival as well as increased the number of festival programs and activities in order to make the festival more interesting [8]. For example, the grand worshipping procession and the ten-god vehicle parade which has been modified from the ancient ceremony, the light and sound performance entitled 'Phanom Rung Maha Tewalai' to praise the king who built and protected the sanctuary, as well as provide a traditional dinner named 'Hope Bai Dinner' to promote the local food and beverage. Moreover, expanding the time period into two or three days for the festival has provided convenient facilities and infrastructure to facilitate visitors. As mentioned, this festival has various programs and activities that have attracted lots of visitors, both domestic and international, to attend. Therefore every year, the organizers have tried to develop the programs and activities to become more interesting and up to date at the same time while highlighting the programs such as the grand worshipping procession and parade, traditional dinner, and light and sound performance [8].

\section{Methodology}

This typology of the study is a survey research in which information and data would be gathered by means of questionnaire, in-depth interviews, and site observation. The first method is an in-depth interview to explore the organizers' attitude on festival management of The Phanom Rung Festival. The second method is a survey-questionnaire to explore visitors' attitude about the 
management of the Festival. The output of the study would partly help the researcher identify the factors contributing to the success of cultural festival management. The outcomes from the study serve an entry point to set up guidelines and/or model for systematically and sustainably managing a cultural festival. The following are the details of the research methodology:

\subsection{Population and sampling size}

The population for the study divided into two groups; the organizers, and the visitors. The festival organizers from four major organizations: the office of Burirum province, the office of Phanom Rung Historical Park, and Tourism Authority of Thailand (Northeast Region1) and the community and visitors, particularly domestic tourists. The sampling size was divided into two groups: 1) 20 organizers determined by a purposive technique and 2) 398 visitors who attended the festival determined by Taro Yamane formula.

\subsection{Research instruments and data collection}

This study based on both quantitative and qualitative approaches, research instruments for data collecting comprised of questionnaire, in-depth interviews, and site observation.

Questionnaire was designed for collecting the data from visitors in order to explore the visitor's attitude about the management of The Phanom Rung Festival This accidental technique was applied for the study. This process was done during the festival period; 2-3 April 2005.

In-depth interviews In-depth interviews were applied to monitor the organizers' opinions about the management of The Phanom Rung Festival in terms of the organization, the programs and activities, the venue. The interview process was primarily done before and after the Festival's duration in order to know the readiness and feedback of the Festival's management.

\subsection{Data analysis}

According to the way the data was collected, the data will be analyzed as follows:

Quantitative method: the data was analyzed based on statistic values i.e. frequency, percentage, means, and standard deviation. The outcomes generated from the analysis serve as the overall objective of the study.

Qualitative method: the data was analyzed based on event management concept in order to identify crucial factor contribute to the success in cultural event management and how do those factors influence on sustainable tourism at The Phanom Rung Festival.

\subsection{Conclusion and recommendations}

Outputs were complimented through an analysis and evaluation in accordance with the research objectives and research questions to identify the effectiveness 
strategy being proposed for the management. The outcomes of the study in forms of guidelines will be generated as recommendations for improving The Phanom Rung Festival's management to be effective and conducted in a sustainable manner.

\section{Results}

Three hundred ninety-eight surveys were collected for the study in which the demographic and travel behavior characteristics of respondents were presented. Most of the visitors were male, aged between 15 and 25 years old. Most of the visitors had a Bachelor level of education and were government officers with an income of 5,000-10,000 Thai Baht. The location of the residents was also from Burirum province, and most of the visitors had previous experience in visiting The Phanom Rung Festival. They obtained the Festival information through their relatives and friends, so most of the visitors attended The Phanom Rung Festival with family members and travelled by their own car. Furthermore, most of them will attend the Festival again.

Visitor's opinions toward the effectiveness of The Phanom Rung Festival: most of the visitors agreed that the management of The Phanom Rung Festival was of a good level, which is seen with a rating of 3.56. Regarding the category of management, most of the visitors thought that the light and sound performance entitled 'The Phanom Rung Maha Tewalai' had the most excellent category (rated at 3.94) whereas the management of the traditional dinner named 'Hope Bai Dinner' was at 3.72, and the third one was the staff service at 3.65. Similarly, organizer's opinions they agreed that three factors contributed to the success of the festival; the uniqueness of the festival and the venue (the Phanom Rung Sanctuary) also the program and activities attracted all visitors attend the festival, another factor was the visitors especially international tourists, the last factor was safety and security of the festival.

The results illustrated that both visitors and organizers strongly recommend that The Phanom Rung Festival programs and activities are crucial factor to contribute to the success in cultural event. As Shone and Parry [7] stated that uniqueness is important to make visitors remember and decide to participate in the festival. Additionally, uniqueness is the thing that makes the festival distinguished from others.

\section{Discussion and conclusions}

The Phanom Rung Festival was created from the faith and belief of Thai and Khmer people to the holy objects at the Phanom Rung sanctuary. The festival was held annually in April because this period was the New Year for Thai and Khmer traditions. Besides, the people believe that once in their life if they come to the Phanom Rung sanctuary and make merit to the holy objects, it could help them be happy, healthy, and wealthy all year. Therefore, in every year lots of people attend the festival in order to make worship and participate with the festival programs both day time and night time. 
As the results from the study there are three main crucial factors to contribute to the success for The Phanom Rung Festival, Burirum province. Firstly, uniqueness of the festival programs that concerning ritual and ceremony makes the festival distinguished from others. The program begin with the grand worship procession (modified from rededication at the Phanom Rung Sanctuary) following with the parade of ten-god vehicle (reinvented version). In the evening present the traditional dinner named 'Hop Bai Dinner' together with traditional music and dances. Ending day with light and sound performance entitled 'The Phanom Rung Maha Tewalai'. As mentioned about illustrated that the overall of this festival theme remained the old tradition although some of the ceremonial programs are reinvented version.

Concerning organizers of The Phanom Rung Festival comprise of three major sectors namely, the office of the Burirum province responding the festival operation, the office of the Phanom Rung Historical Park responding the festival venue, and the Tourism Authority of Thailand who responding the festival promoting. Almost of the organizers were the people in Burirum province they emphasize that this festival makes them proud and aware to preserve their cultural heritage continuity even though globalization. Moreover, The Phanom Rung Festival acts as a tool to present both Thai and Khmer traditional cultural heritage widely.

\section{Reference}

[1] Zeppal H, \& Hall, C.M. (1991). Selling Arts and History: Cultural Heritage and Tourism. Tourism Studies. Vol.2.

[2] Bowding, G.A.J., Mc Donell, I., O’Toole, W. (2001). Event Management. Butterworth Heinemann, Australia.

[3] Reungdej Phumjit. (1986). The Phanom Rung Festival, Burirum province Cultural Centre, Burirum

[4] Suksom Nongkran. (2005). Historical Context towards The Phanom Rung Festival. Muang Boran, 112-119. Bangkok.

[5] Allen, Johnney, O’Toole, William, Mc Donell, Ian, and Harris, Robert. (2000) Festival and Special event management. Australia: John Wiley \& Sons Australia, Ltd.

[6] Getz, Donald. (1991). Festival Special Events and Tourism. New York: Van Nostrand Reinhold.

[7] Shone, Anton with Parry, Bryn. (2001). Successful Event Management; A Practical Handbook: Continuum London and New York.

[8] Reungdej Phumjit. (2000).The Phanom Rung Festival, historical background of Phra Nang Bhupatintoralaksamee Dhevi procession. Cultural Centre, Burirum. 